Para enlazar con este artículo / To link to this article:

http://dx.doi.org/10.14198/fem.2018.32.04

Para citar este artículo / To cite this article:

Parra-Martínez, José \& Crosse, John. «Grace Morley, the San Francisco Museum of Art and the Early Environmental Agenda of the Bay Region (193X-194X)». En Feminismo/s, 32 (diciembre 2018): 101-134. Dosier monográfico: MAS-MES: Mujeres, Arquitectura y Sostenibilidad - Medioambiental, Económica y Social, coord. María-Elia Gutiérrez-Mozo, DOI: 10.14198/fem.2018.32.04

\title{
GRACE MORLEY, THE SAN FRANCISCO MUSEUM OF ART AND THE EARLY ENVIRONMENTAL AGENDA OF THE BAY REGION (193X-194X)
}

\author{
GRACE MCCANN MORLEY Y EL MUSEO DE ARTE \\ DE SAN FRANCISCO EN LOS INICIOS DE LA AGENDA \\ MEDIOAMBIENTAL DE LA REGIÓN DE LA BAHÍA \\ $(193 X-194 X)$
}

José PARRA-MARTÍNEZ

Universidad de Alicante jose.parra@ua.es orcid.org/0000-0003-0142-0608

John CROSSE

Retired Assistant Director, City of Los Angeles, Bureau of Sanitation, California jocrosse@ca.rr.com

\begin{abstract}
This paper addresses the instrumental role played by Dr Grace L. McCann Morley, the founding director of the San Francisco Museum of Art (1935-58), in establishing a pioneering architectural exhibition program which, as part of a coherent public agenda, not only had a tremendous impact on the education and enlightenment of her community, but also reached some of the most influential actors in the United States who, like cultural critic Lewis Mumford, were exposed and seduced by the so-called Second Bay Region School and its emphasis on social, political and environmental concerns. A number of seminal shows on architecture, landscape architecture and planning mounted under Morley, such as Telesis group's 1940 Space for Living,
\end{abstract}

Los contenidos de la revista se publican bajo una licencia de Creative Commons Reconocimiento 4.0 Internacional (CC BY 4.0)

Feminismo/s 32, diciembre 2018, pp. 101-134 
engaged San Francisco Bay Area citizens in proposals of 'smart' urban growth relying on thoughtful land usage, natural preservation and regional integration, decades before the coining of terms like 'environmentalism' or 'sustainability'. Archival research involving the examination of exhibition records and correspondence, as well as other primary sources, such as journal articles and oral histories, are compared with recent historiographical accounts to provide a better understanding of some crucial episodes in the early history of the Bay Region's environmental movements. The contributions of remarkable women like Grace Morley and her close circles of female collaborators, including Dorothy Erskine, Catherine Bauer and her sister Elizabeth Mock, are to this day highly under-recognized.

Keywords: Grace McCann Morley, San Francisco Museum of Art, architectural exhibitions and public education, regionalism, environmental thinking.

\section{Resumen}

Este estudio aborda la figura de Grace L. McCann Morley, fundadora y directora del Museo de Arte de San Francisco (1935-58). Su innovador programa de exposiciones de arquitectura no sólo resultó fundamental en la educación y sensibilización medioambiental de su comunidad, sino que alcanzó también a algunos de los actores y críticos más influyentes del país, como Lewis Mumford, que fueron seducidos por la denominada Escuela de la Región de la Bahía y su énfasis en la condición social, política y medioambiental de la arquitectura. Gracias a la intensa agenda pública de Morley y a exposiciones como Space for Living, comisariada en 1940 por el grupo Telesis, la ciudadanía de San Francisco se involucró en la defensa de un uso más sensible del territorio y la preservación de los recursos naturales de la región, varias décadas antes de que términos como 'medioambiente' o 'sostenibilidad' fuesen de uso común. Partiendo de una investigación de archivo, así como fuentes primaras (artículos de revistas y entrevistas históricas) contrastadas con relatos historiográficos recientes, se pretende esclarecer algunos episodios formativos en la historia temprana de la conciencia medioambiental del Área de la Bahía. Llamativamente, la decisiva contribución al pensamiento y activismo de varios movimientos cívicos locales por parte de mujeres extraordinarias, como la propia Grace Morley y sus círculos de colaboradoras, entre ellas Dorothy Erskine, Catherine Bauer y su hermana Elizabeth Mock, apenas ha sido estudiada todavía y, por tanto, reconocida.

Palabras clave: Grace McCann Morley, Museo de Arte de San Francisco, exposiciones de arquitectura e instrucción pública, regionalismo, pensamiento medioambiental. 
«Architecture is either the prophecy of an unfinished society or the tomb of a finished one.» Lewis Mumford, 1934. «This land, this red land, is us.» John Steinbeck, 1939.

\section{INTRODUCTION}

This essay examines some of the substantial contributions made by Dr Grace L. McCann Morley, founding director (1935-58) of the San Francisco Museum of Art (SFMA), to the public's understanding and subsequent valorization of the environmental movement emerging in the late 1930s around San Francisco Bay as a response to the overlapping political, demographic and socioeconomic upheavals that would ultimately shaped its physical and cultural geography. Over the decades spanning from the Great Depression to the beginning of the Cold War, San Francisco rapidly evolved from a medium-sized, port city into the core of a complex metropolitan economy whose expansion had already begun soon after the 1915 Panama-Pacific Exposition and accelerated during the war effort. Major urban redevelopments and infrastructural transformations disrupted established patterns of territorial, spatial and population dynamics across the region, resulting in new forms and scales of interaction between nature and the built environment. During the process, the ethos of the Northern California landscape, with its balance of urbanized realms, unique agricultural territories and magnificent natural vistas became a key driving force behind the Bay Region's progressive architectural and planning culture.

Focusing on the San Francisco Museum of Art's early years under Grace Morley, this paper discusses the first major shows she devoted -in chronological order- to landscape architecture (1937), regionalist architecture (1938) and planning (1940). Three noteworthy events which, not only set high standards for future displays at SFMA but also pushed the boundaries of exhibitions as a medium of instruction and marked seminal moments in the public's recognition of the central role of place. Although Morley's pioneering work is now widely celebrated in the realm of avant-garde art, her contributions to the history of modern architecture still remain unexplored. Her friendship and ongoing collaborations with leading architects, landscape

Feminismo/s 32, diciembre 2018, pp. 101-134 
designers and planners, from the local environmental research group Telesis to figures of national stature like William W. Wurster and Thomas Church, resulted in a number of exhibition projects which championed the inherent natural and social values of the Bay Area and the need to reintegrate them as the keystone of every design practice.

This study also aims to bring attention to the insufficiently documented work of other prominent female activists in Morley's close circles, either professional women and scholars such as Catherine Bauer or semi-professional social reformers like Dorothy Erskine, who were also involved in the preparation for several shows at SFMA. By inspiring, supporting or cooperating with their male partners, these women contributed to sparking new concerns about the right management of natural resources in the Bay Area and, in return, the environment's potential to affect people's well-being. Decades before sustainability became a mainstream concept, they struggled to defend multilateral approaches to modern architecture and regional planning and put forth an early environmental agenda which laid the foundations for the Bay Area's legacy in the recent history of preservation movements and green policies.

\section{GRACE MORLEY, A FORGOTTEN PIONEER IN MODERN ART MUSEUMS}

Grace Morley was a Bay Area native who, after graduating with bachelor's and master's degrees from the University of California, earned a doctorate in French art and literature from the University of Paris. Her career had begun in 1930, when she joined the Cincinnati Art Museum as general curator. Four years later, Morley returned to San Francisco to fill the void left behind by the dismissal of Lloyd LaPage Rollins, who had directed the M. H. de Young Memorial Museum and the California Palace of the Legion of Honor between 1930 and 1933, when he was fired for being too far ahead of his time but also for being a homosexual ${ }^{1}$. Moving away from the more classic purposes of these two art institutions, the San Francisco Museum of Art opened on January 18, 1935, on the fourth floor of the War Memorial Building in San

1. Ironically, in 1958, Morley most likely had to resign as well her post for being a lesbian. Regarding this episode see Megan Martenyi's 2017 essay which delves into Morley's life outside the museum walls to find the extent to which she may have discretely moved

Feminismo/s 32, diciembre 2018, pp. 101-134 
Francisco's Civic Center, becoming the only museum on the West Coast devoted solely to modern ${ }^{2}$ art. Thanks to Morley's extraordinary talent and political savvy, by the mid-1940s, it had already secured its position as the country's second museum of its kind.
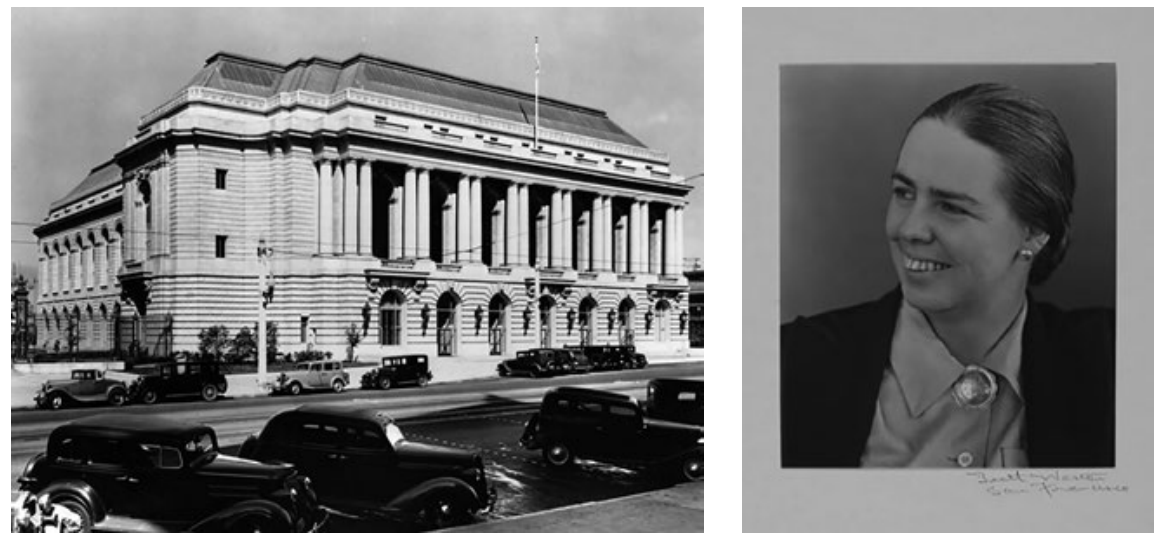

Figure 1. Arthur Brown's 1932 War Memorial Building, Civic Center, San

Francisco. Moulin Studios (left). Grace Morley, Portrait by Brett Weston, 1940. San Francisco Museum of Modern Art archives, SFMOMA (right)

Grace Morley, who ran SFMA until her resignation in 1958, was a habitué of San Francisco's avant-garde groups, as well as of local cultural and academic institutions, such as the California School of Fine Arts (CSFA), with which she teamed up to promote a wide-ranging collaboration between the international art scene and regional art movements. Despite her not yet being widely accepted by many wealthy San Francisco art patrons, she began her directorship by inviting now canonical figures like Mark Rothko, Jackson Pollock and Diego Rivera whom she actively introduced to her local audiences.

Morley's cultural leadership in the Bay Area was all about her context, «and was for the public, not herself» (Martenyi). Morley was not an elitist

through San Francisco's queer social worlds, as she could not be openly gay because of her position and the constraints of her time.

2. The word 'modern' was officially added to the museum's name in 1976, when it was changed to the San Francisco Museum of Modern Art (SFMOMA).

Feminismo/s 32, diciembre 2018, pp. 101-134 
adherent of modern art. On the contrary, she believed passionately in cultural democracy -that art should be available to everyone (Kirk 71) and since «the public she envisioned and worked for was not organized around sameness, but difference», she «was constantly negotiating to cultivate and maintain the San Francisco Museum of Art as an egalitarian public space and cultural beacon in the face of social and political pressures» (Martenyi).

Morley's vision was to make SFMA «a site for experimentation» and «interactive learning» (Kirk 71). In her struggle to involve her diverse audiences into the many fields of contemporary art and their intersections, she understood that a modern museum had to present and discuss the most recent achievements in contemporary creation through a multiplicity of media, which included design, architecture, planning, photography ${ }^{3}$, television, and the launching of the first regular art film program at an American museum.

Morley also maintained an active participation in several art associations and public organizations. She worked extensively for the American Association of Museums, the American Association of Art Museum Directors and the American Federation of Arts (AFA), where she was elected Vice President. After the war, SFMA gained prominence ${ }^{4}$ and she became an expert of global influence who dedicated herself to high-profile international programs such as UNESCO's, for which she served as the first Head of the Museum Division.

In the fields of architecture, landscape architecture and planning, Morley's far-reaching activity still remain unexplored. She commissioned extraordinary shows which rapidly captured the attention of the two most significant California architectural magazines, Los Angeles's California Arts \& Architecture and San Francisco's Architect and Engineer. Morley became a member of the advisory board ${ }^{5}$ of the former and contributing a monthly column to the

3. Such as the work of her friends Edward and Brett Weston, Ansel Adams, Imogen Cunningham, Dorothea Lange, Minor White and many others.

4. In 1945, SFMA became the birthplace of the United Nations, an historic event to which Morley personally contributed by clearing off and setting up the galleries of the Veterans War Memorial Building for the signing of the UN Charter.

5. In the May, 1940, issue of $C A \mathcal{E} A$ Grace Morley and her frequent collaborator, textile designer Dorothy Liebes were named to the editorial advisory board of John Entenza's recently acquired magazine.

Feminismo/s 32, diciembre 2018, pp. 101-134 
latter. Likewise, her national connections secured the coverage of her museum's architectural exhibitions through a variety of national channels, among which, in the field of architecture, the Western section of Architectural Record, Architectural Forum and AFA's Magazine of Art would be instrumental in the promotion of Bay Region architects.

Notwithstanding her reputation and professional network, Morley had to overcome a number of significant financial, geographic, and philosophical challenges, «especially as a woman working outside the East Coast art establishment» (Kirk 71) who refused to adhere to conventional standards of femininity (Martenyi). Evidence of her promethean efforts to champion avant-garde culture is that, during her first years as director, she managed to mount dozens of exhibitions and to host a wide range of educational talks, gallery tours and modern art courses. Such a vigorous schedule responded to Morley's anti-elitist purpose «to get the public into the habit of visiting frequently by making sure there was always something new on display» (Kirk 72). Morley was also ahead of her time when she made the decision of keeping the museum open until ten in the evening on weekday nights (Morley, «Art, Artists, Museums» 61-62) and also to organize late-night events, which allowed attendance by those busy in the daytime.

In her 1982 oral history interview, Morley recalled the many difficulties of sustaining late-night access to the museum during World War II. Yet, to her, it was a paramount goal to continue this policy and motivate her audiences during the dreadfulness of wartime. Morley's resolution and perseverance were crucial in achieving all these goals in spite of SFMA's chronic shortage of funds. As a private institution, it had a Board of Trustees and counted on the support of different patrons and organizations, however it operated with a very small staff assisted by a public-spirited group of female volunteers, largely provided by the Women's Board. This group of dedicated women made the most of helping Morley establish her museum's roots in the community and to make SFMA part of their fellow citizens' lives (Morley, Oral History). Morley held firm convictions that museums served a central social function and perhaps, as Megan Martenyi suggests, the sense of place and civic purpose which grounded her SFMA stewardship might have also emerged from the solidarity of the constantly harassed gay and lesbian communities she frequented amid rises in fascism and McCarthyism.

Feminismo/s 32, diciembre 2018, pp. 101-134 


\section{CONTEMPORARY LANDSCAPE ARCHITECTURE (1937)}

In February 1937, the San Francisco Museum of Art produced Contemporary Landscape Architecture. It was SFMA's first ${ }^{6}$ major show devoted to landscape architecture and, as an exhibition on modern landscape design, the first of its kind ever mounted internationally. The show was assembled and curated by Morley herself, counting on the assistance of her closest architectural circles. Among them, landscape architect Thomas Church and architects Ernest Born, Morley's SFMA trustee Gardner Dailey and William Wurster held central positions in the show through which their work was introduced to SFMA's audience for the second ${ }^{7}$ time.

In America the issue of landscape architecture had been presented to the public separately, either in specialized books or in women's shelter magazines which published fashionable combinations of regional houses and picturesque gardens. National journals such as Fortune, House Beautiful, Ladies Home Journal, etc., and, in California, Sunset magazine and the pre-Entenza's California Arts \& Architecture (CA\&A) extensively promoted landscape design. Grace Morley brought the topic into the museum and made its relationship with modernism a matter of utmost concern simultaneously for both popular and high culture.

SFMA's decision to organize a show on the topic of landscape design was in tune with its attendee's appreciation of the dramatic settings of San Francisco Bay. The exhibit was backed by Morley's professional network and benefited from the participation of the American Society of Landscape Architects and the University of California Berkeley Department of Landscape Design. Its discourse echoed local architects' concern about the relation between the modern house «and the garden 'to live in' as an integral part of itself» (Morley, «Foreword» 13). Contemporary Landscape Architecture emphasized the integration of outdoor space into the domestic realm as a distinct attribute of

6. Actually, the first show the SFMA devoted to architecture had taken place in 1935 as a biennial exhibition of AIA licensed architects' award-winning projects. However, being an assembly of existing materials, one can consider that the first comprehensively directed, selected and designed full-scale architectural exhibition to be Ernest Born $>$ 1938 event.

7. See previous note.

Feminismo/s 32, diciembre 2018, pp. 101-134 
California modernism, being the reason why such an exhibition presenting «consistent experimentation in gardening [and] adaptation to the site» had been mounted for the first time in San Francisco (Morley, «Foreword» 13).
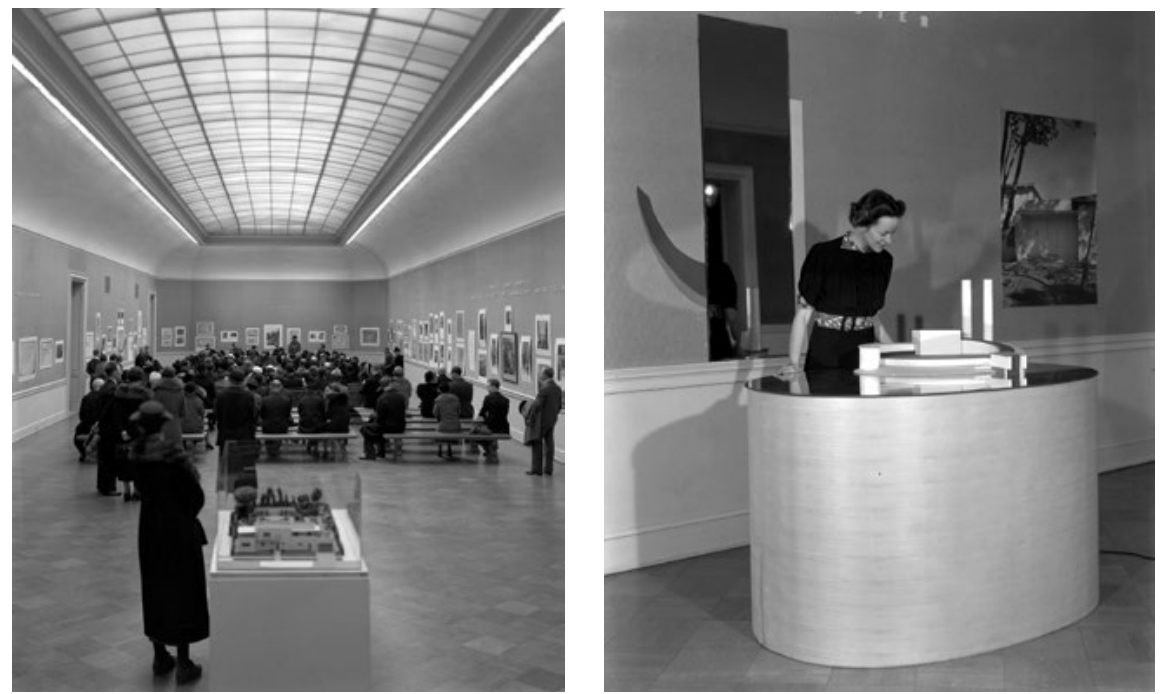

Figure 2. Gallery talk (left) and model exhibited at the 1937 Contemporary Landscape Architecture show (right). Courtesy of SFMOMA archives

Morley encouraged the presentation of a coherent body of landscape practices, carefully illustrated through blueprints, photographs and models explaining the many implications of a topic that had begun to receive attention, she said, when modern architecture was finally released from the limitations of function. Morley's pedagogical effort is particularly evident in the structure of the exhibition catalogue. It included historical sections devoted to the background, philosophy, and sources of contemporary landscape design, to which Henry-Russell Hitchcock and Richard Neutra, among others, respectively contributed an introduction and essays.

Acclaimed by both the professional press and lifestyle magazines, the show was extensively covered by San Francisco-based Architect and Engineer and Sunset, both of which began prominently featuring SFMA's activities on a monthly basis. Being the first of various exhibitions devoted to landscape architecture, the 1937 show succeeded in many goals: it emphasized the

Feminismo/s 32, diciembre 2018, pp. 101-134 
importance of context, attracted public attention to modern landscape architecture, inspired a younger generation, and increased the national prestige of Bay Area designers.
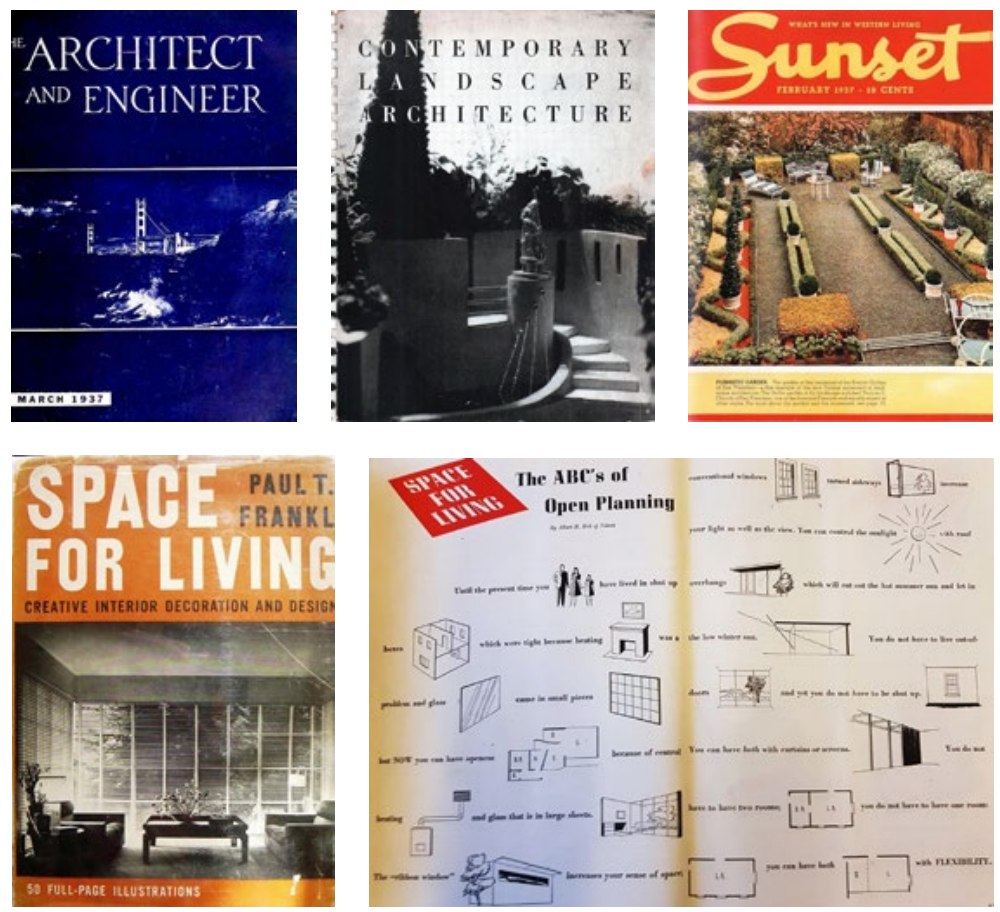

Figure 3. Up: Architect \& Engineer, March 1937 issue featuring SFMA's exhibition Contemporary Landscape Architecture (left); SFMA's 1937 exhibition catalogue cover (middle); Sunset magazine, February 1938 cover of the issue featuring Contemporary Landscape Architecture (right). Down: Sunset magazine's pages covering SFMA's Space for Living show, July 1940 issue

Late in 1948, during Morley's time in Paris with UNESCO, SFMA mounted a second major landscape show, just at the peak of the national debates on regionalism and style. It was titled Landscape Design ${ }^{8}$ and expanded its

8. During Grace Morley's absence at UNESCO, Assistant Director Richard Freeman provided continuity with her activities and was responsible for prefacing the exhibition catalogues of 1948 and 1949.

Feminismo/s 32, diciembre 2018, pp. 101-134 
scope to include planning and social housing. Among the contributors to the exhibition catalogue were -then MIT Architecture School dean-William Wurster, artist and CAEA's columnist Claire Falkenstein, landscape architect and scholar Christopher Tunnard, and Sunset editor Walter L. Doty. Their commitment to this new exhibition indicates the prestige Morley had built for her museum as a hotbed of discussions on landscape issues. Another crucial show on the topic was organized under Morley in 1957, including the work of Douglas Baylis, Thomas Church, Garret Eckbo, Lawrence Halprin and Geraldine Knight Scott as some of the most significant exponents of Bay Region's modern landscape design. These three exhibitions coincided with the meetings of the American Association of Landscape Architects in San Francisco, evidencing a two-decade collaboration between Morley and experts of national reputation ${ }^{9}$.
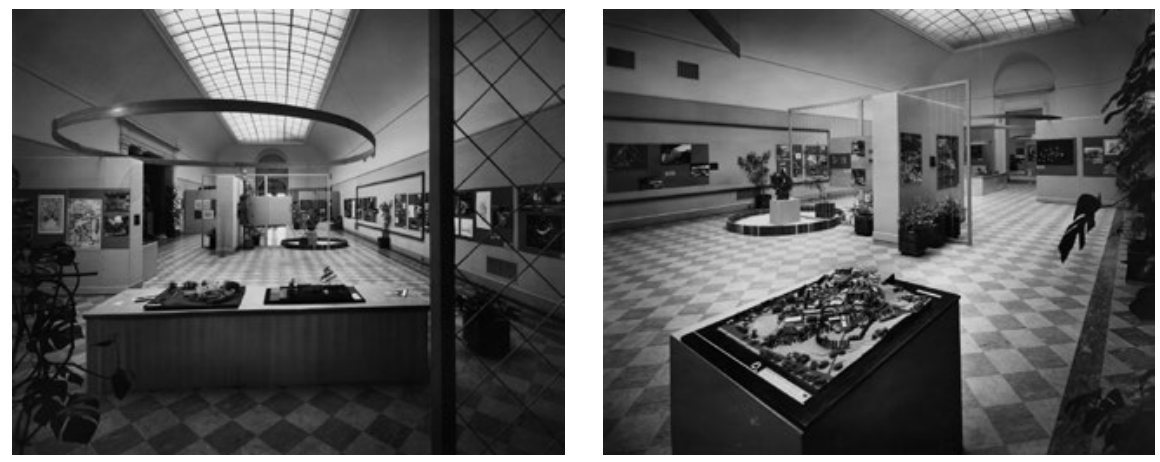

Figure 4. Installation of 1948 Landscape Design show at SFMA. Courtesy of SFMOMA archives

Due to SFMA's financial restrictions, not many events had an accompanying catalogue and the fact that, unlike architecture shows, all landscape architecture exhibitions resulted in a publication speaks volumes about Morley's determination to promote innovative reflections on landscape architecture. Grace Morley's 1937 and 1948 exhibition catalogues, along with Cristopher Tunnard's 1938 Gardens in the Modern Landscape book significantly influenced

9. Douglas Baylis letter to Grace Morley, April 19, 1956. SFMOMA Archives: ARCH. EXH.001, box 48, folder 16 . 
future publications, such as Garret Eckbo's 1950 landmark text Landscape for Living $^{10}$. It summarized a decade of landscape design practices in California, highlighting that they were not merely a matter of visual recreation but aimed to create continuous interaction between people and place, «between man and the land» (Eckbo, Space for Living 6).
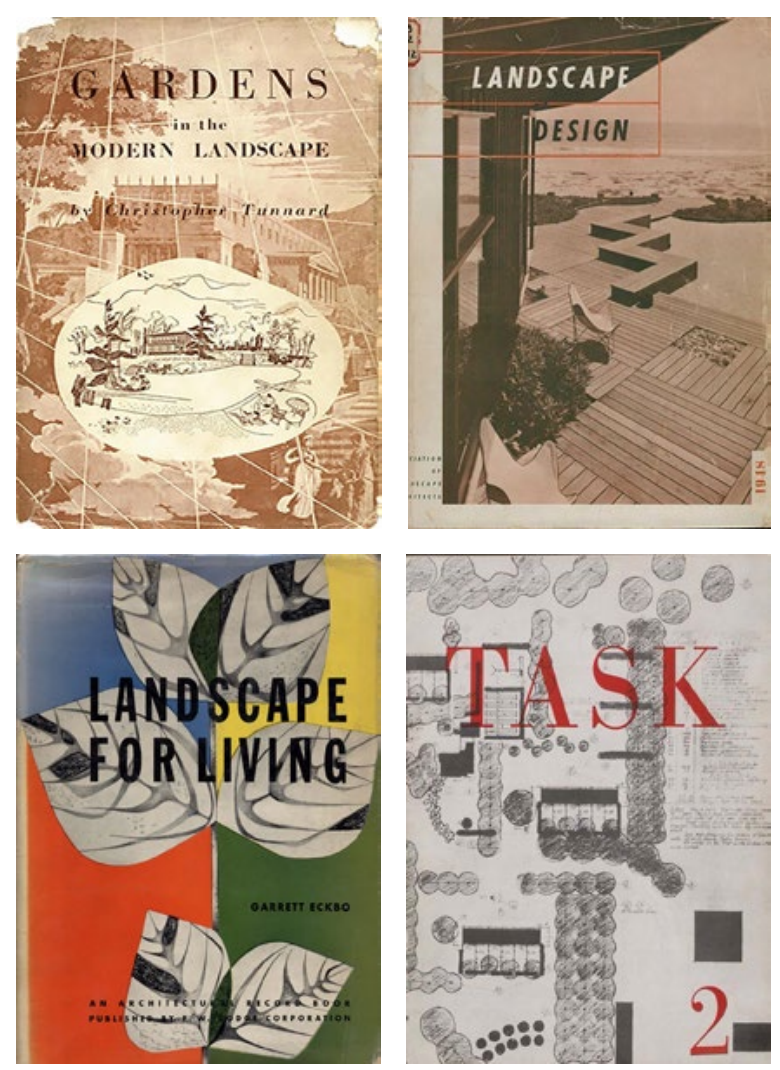

Figure 5. Up: Covers of Christopher Tunnard's 1938 Gardens in the Modern Landscape (left) and 1948 Landscape Design exhibition catalogue (right). Down: Garret Eckbo's 1950 Landscape for Living (left) book and Ecko's cover design for Task 2, 1941 featuring a planting plan for FSA multifamily houses project in California (right)

10. This was a riff on Eckbo's coining of «Space for Living» as the title for SFMA's 1940 Telesis exhibition.

Feminismo/s 32, diciembre 2018, pp. 101-134 


\section{GRACE MORLEY'S EARLY ARCHITECTURE PROGRAM (1938-41)}

In September 30, 1938, SFMA premiered its first great architectural exhibition of juried works entirely devoted to Bay Area modernism. The show was entitled AIA Exhibition of Northern California Licensed Architects and focused primarily upon domestic architecture. As chairman of the exhibition committee, William Wurster proposed San Francisco architect, designer and illustrator Ernest Born to curate and design the show. This exhibition was formative in its intention to promote a clear image of the Bay Area as a coherent architectural region notwithstanding the variety of projects. Although private residences were an important part of the show, social housing was also present with United States Housing Authority contributions via Wurster's soon-to-be wife, housing expert Catherine Bauer ${ }^{11}$.

From the beginning of its preparation, Morley had insisted on the importance of thinking about every architectural event at SFMA from the layperson's point of view. Her correspondence with Wurster reveals her pedagogical struggle to get the message out to the public. She constantly insisted on making architectural exhibitions more attractive to the non-expert «than such shows usually are» ${ }^{12}$, elucidating that, since her main goal was to prompt visitors' curiosity, in order to achieve a convincing outcome, the selection of participants had to be very restrictive and consistent with the topic.
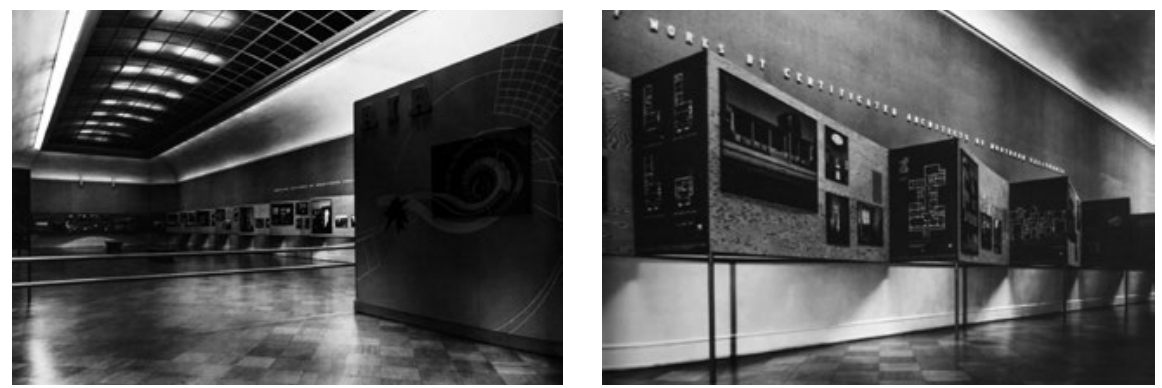

Figure 6. Ernest Born's 1938 AIA Exhibition of Architecture at SFMA's North Gallery. Architectural Forum, Dec. 1938

11. Catherine Bauer letter to SFMA, December 15, 1938. SFMOMA Archives: ARCH. EXH.001, box 9, folder 23 .

12. Grace Morley letter to William Wurster, January 15, 1938. SFMOMA Archives: ARCH. EXH.001, box 9, folder 23 . 
Being in full charge of choosing and organizing the exhibition material, Ernest Born was responsible for bringing Morley's vision to life. Yet, Born had to grapple with strenuous resistance from his colleagues, as he refused to play favorites. Instead, he decided to present the ensemble of the forty selected works in an unprecedented systematic and uniform manner (Olsberg 173). The show's different sections were arranged as an itinerary along the walls of SFMA's North and West galleries, which were covered by a series of boards laid out on a saw-tooth plan. Each project was explained in two panels -the first devoted to blueprints of floorplans, the second to large-scale photographs- which unfolded like the pages of an inviting book. The exhibition was a complete popular success. As Morley had envisioned, San Franciscans responded so positively that the closing date of the exhibit was extended for two more weeks to accommodate the unexpected number of visitors. This, in turn prompted Morley to further enhance and continue her programs on modern architecture.

In this and subsequent displays at SFMA, Ernest Born collaborated with his wife, architectural photographer Esther Born. The primarily visual documentation of their exhibitions consisted of exceedingly handsome black and white pictures taken by Esther. To provide visual coherence, the architectural plans were all redrawn and printed for each exhibition. The 1938 event set an exceedingly high standard for futures shows. Local and national press immediately remarked ${ }^{13}$ upon the architect's ground-breaking and extremely appealing installation whose innovative design was without parallel in the United States. No other museum in the country, including MoMA, had as yet arisen to this challenge. In fact, the originality and quality of Born's first proposals at SFMA might be only comparable to the experimental work that George Nelson was by then producing for the New York Architectural League.

13. Architectural Forum laid emphasis on the simplicity and visual order accomplished by Born's refined design, which was «a complete reversal of the usual practice of fitting together whatever material available might be» (468).

Feminismo/s 32, diciembre 2018, pp. 101-134 

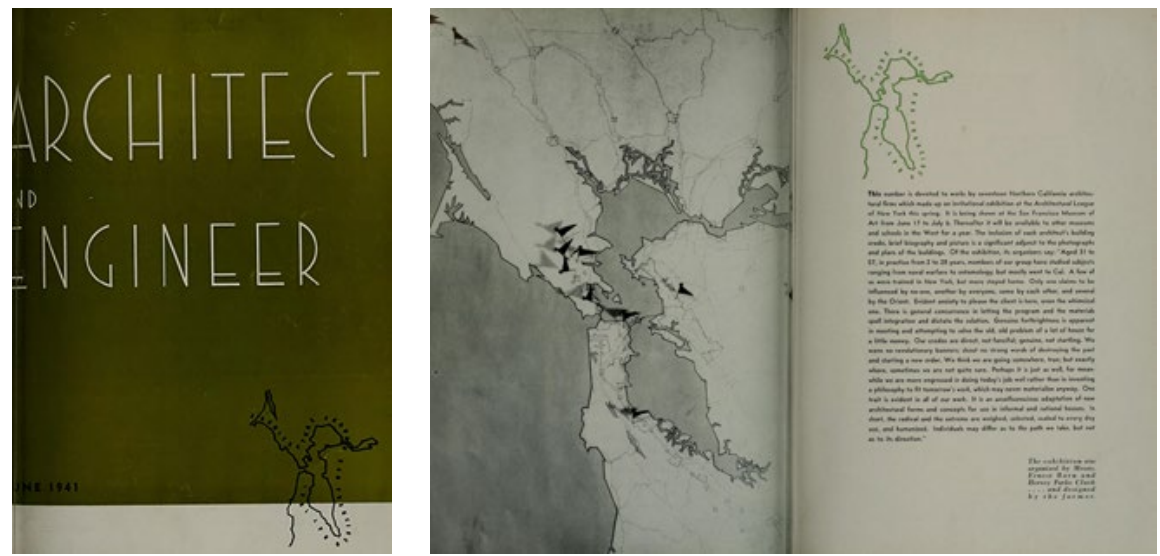

Figure 7. Cover (left) and Ernest Born's presentation (right) of the June 1941 issue of Architect $\&$ Engineer which served as the Architecture Around San Francisco Bay exhibition catalogue

The 1938 show was the first of a series of three architectural exhibitions which contributed decisively to the process of codification of Bay Area regionalism. Another landmark show came in 1941 to take full advantage of the first AIA National Convention in California in May. It was called Architecture Around San Francisco Bay (AASFB) and would be mirrored by the famous 1949 exhibition Domestic Architecture of the San Francisco Bay Region (DASFBR), which was organized to make the most of the stir caused by MoMA's «What is Happening to Modern Architecture?» symposium organized the previous year under Philip Johnson's tutelage to refute Lewis Mumford's arguments on the alleged existence of a «Bay Region Style» ${ }^{14}$ as a «free yet unobtrusive expression of the terrain, the climate and the life on the Coast» (Mumford, "The Sky Line»109). All these three exhibitions were designed by Ernest Born, who himself explained his fellow architects' regionalist approach in terms of adaptation to site, simplicity in the handling of the available materials, and casual approach to architectural space (Born 25) years before Mumford

14. The term would be dismissively used by Alfred Barr against Lewis Mumford during the 1948 MoMA symposium when he dubbed Mumford's original 'Bay Region Style' as 'Cottage Style'. Recognizing the misfortune of his previous terminology choice, Mumford called it 'Bay Region School', as his new all-inclusive designation.

Feminismo/s 32, diciembre 2018, pp. 101-134 
published his controversial October 11, 1947 New Yorker column expressing his disaffection with the mechanical and formalist version of modernism proposed by Hitchcock and Johnson at MoMA in 1932.
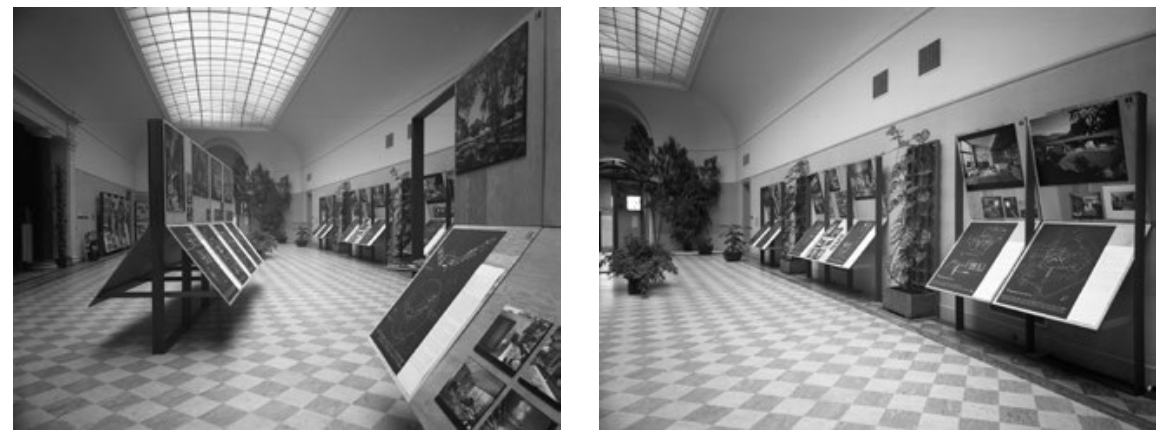

Figure 8. Domestic Architecture of the San Francisco Bay Region. Ernest Born's 1949 installation at SFMA. Courtesy of SFMOMA archives

The 1949 DASFBR show coincided with the culmination of nearly a decade of cooperation between the two main museums of the country. Grace Morley's prominent role in the American Federation of Arts as well as her lobbying effort to secure a Western circuit for shows coming from the East primarily resulted in a close collaboration with the Museum of Modern Art, New York, beginning as early as 1937. Morley's close relationship with Alfred Barr, and later with Elizabeth Mock via her sister Catherine Bauer and brother-in law William Wurster, facilitated a number of noteworthy circulating exhibitions borrowed from MoMA, which naturally fit into her architectural programs. Mock's correspondence ${ }^{15}$ reveals that she was collaborating with her sister Catherine and Grace Morley at least since her arrival at MoMA in 1938. This triangle of intertwined personal lives and professional collaborations would explain the vigorous circulation of exhibitions between the two museums during Mock's curatorship at MoMA (1938-1946). This circulation ensured the cultural exchange of progressive ideas regarding modern planning, social

15. Elizabeth Mock letter to Taliesin, April 4, 1940. Frank Lloyd Wright Correspondence. Microfiche copy. The Getty Research Institute.

Feminismo/s 32, diciembre 2018, pp. 101-134 
housing, wartime emergences and, of course, the regionalist standpoint ${ }^{16}$ which, after frequent professional and personal travels to California early in the 1940s, Elizabeth Mock detailed in her major show Built in USA: 19321944. In her foreword to the Built in USA exhibition catalogue -also predicting Mumford's criticism of the International Style- Mock particularly stressed the importance of the Bay Region tradition, which due to her sister's guidance was illustrated though examples of public housing, urban facilities and rural community planning projects by William Wurster and Telesis members Vernon DeMars and Garret Eckbo.
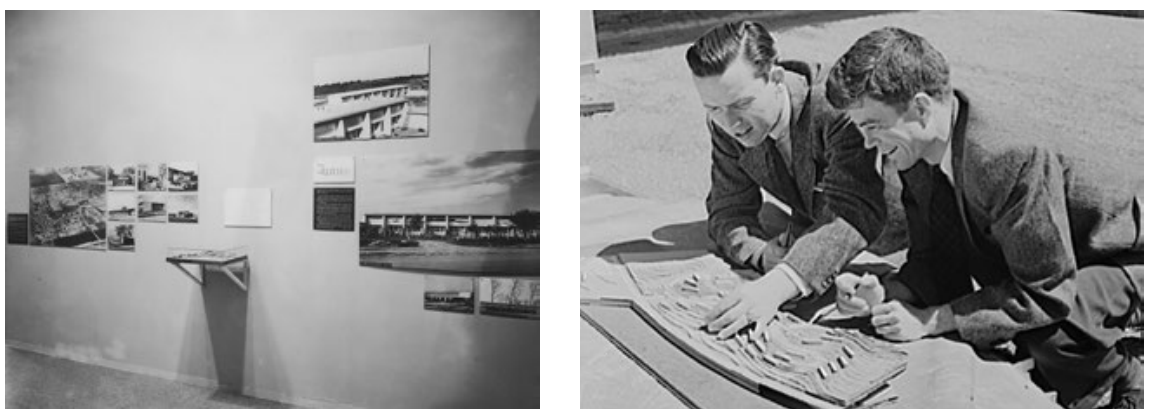

Figure 9. Left: Elizabeth Mock's 1944 Built in USA: 1932-1944 show at MoMA. Vernon De Mars's and Garret Eckbo FSA rural community in Woodville, California. MoMA archives. Right: Vernon DeMars (left) and Garret Eckbo (right) working on site model of the Vallejo defense housing dormitories. Farm Security Administration,

Office of War Information Photograph Collection, Library of Congress

\section{SPACE FOR LIVING (1940): THE FIRST ENVIRONMENTAL APPROACH}

The third seminal show mounted under Grace Morley was Space for Living. An Exhibition of Planning and Architecture. The event was the San Francisco

16. Among Mock's main exhibitions which traveled to San Francisco, the following are revealing of her social concerns: Wartime Housing (1942); Look at Your Neighborhood: Principles of Neighborhood Planning (1944) or If You Want to Build a House (1946) which Grace Morley immediately echoed through her The House I Want program. In turn, MoMA received the influence of California exhibitors and even their exhibitions, like the 1942 Western Living show, which travelled to MoMA under the form and title of Five California Houses, indicating of the cross-pollination between both museums.

Feminismo/s 32, diciembre 2018, pp. 101-134 
Museum of Art's first show entirely devoted to urban and territorial questions and had an immediate impact on the evolution of the Bay Region's planning. It was premiered on Monday, July 29, being open from July 30 through September 1, 1940. Six months before, in February 1940, the content and installation of the show had been entrusted by Grace Morley herself to Telesis, an informal alliance of San Francisco-based designers and progressive thinkers composed for the most part of recent University of California Berkeley graduates. After having met for half a year, Telesis founders took full advantage of Morley's invitation to establish their distinctiveness as a research group and to increase their visibility by putting on an exhibition which, as Telesis female member Geraldine Knight Scott would later recall, was intended as a collective manifesto on «what planning could do for cities» (Knight Scott 8).

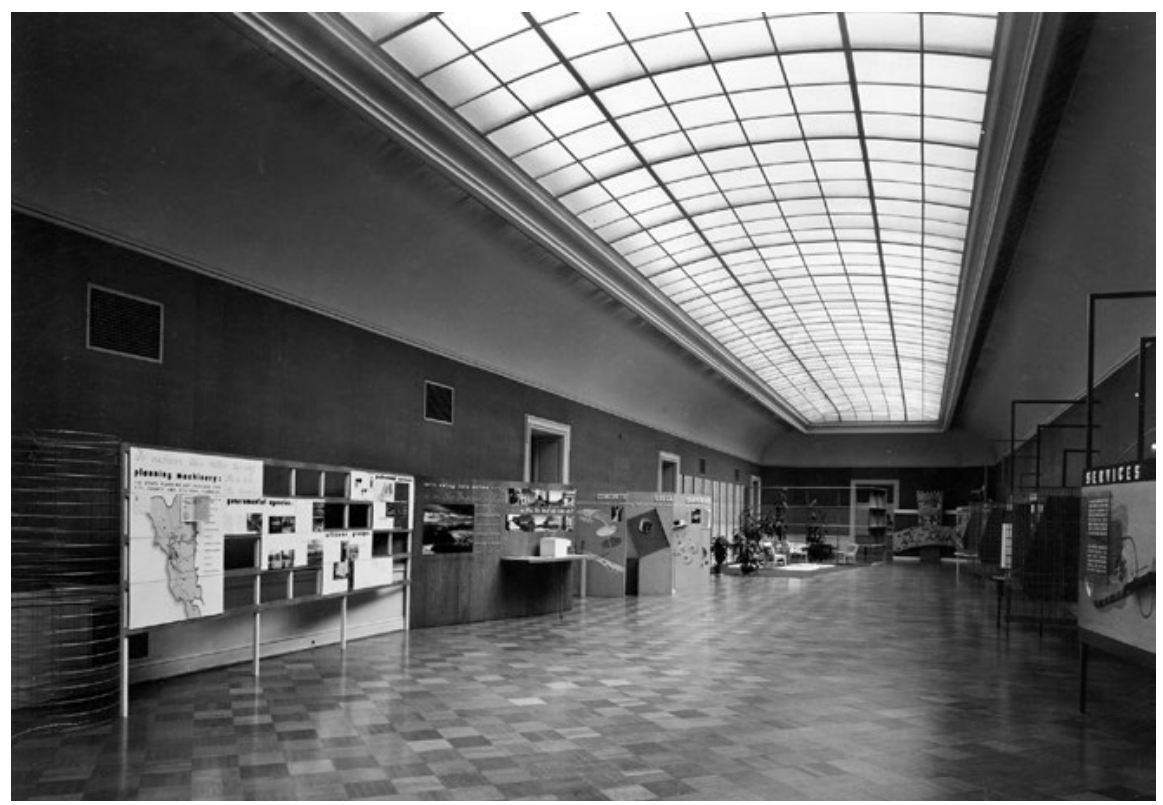

Figure 10. Telesis's 1940 Space for Living exhibition at SFMA's South Gallery.

Courtesy of SFMOMA archives

Feminismo/s 32, diciembre 2018, pp. 101-134 


\subsection{Telesis's Environmental Tour de Force}

Telesis had emerged from their members' lively discussions to confront the principles of European modern planning with the urban culture and geographical context of San Francisco Bay. The first meeting took place early in September, 1939, in one of the group's apartments in Telegraph Hill (Violich, «The Planning Pioneers» 29). The core group, which agreed to develop into a non-hierarchical, democratic collective, included architects Burton Cairns, John Dinwiddie, Joseph McCarthy and Vernon DeMars; planner T. J. (Jack) Kent; landscape architects -and future planners- Garret Eckbo, Corwin Mocine and Francis Violich; industrial designer Walter Landor; and, among other notorious figurers, social reformer and conservationist pioneer Dorothy Erskine. Grace Morley, William Wurster and his wife Catherine Bauer, along with her cohort of female social activists and friends, such as Alice Griffith ${ }^{17}$, were among their regular circle ${ }^{18}$ of contributors and benefactors providing a strong support ${ }^{19}$ to the group.

Vernon DeMars, who would become one of the most influential Californian architects, was a major force in Telesis. After graduating in 1931 he joined the National Park Service and, five years later, was appointed chief architect of the Western Division of the Farm Security Administration (FSA), a Depression-born federal agency where he was in charge of planning and building ingenious, inexpensive settlements for migrant farmers. During his tenure with the FSA, DeMars collaborated with Burton Cairns and Garret Eckbo. He also spent time at the Rural Resettlement Agency with Corwin

17. Catherine Bauer went to Berkeley in 1938 for a one-year appointment as a Visiting Professor in the Social Welfare Department, although she stayed on for another year. During her first time on the West Coast, Bauer participated with Dorothy Erskine to reactivate Alice Griffith's San Francisco Housing Association, which had been created after the 1906 earthquake (DeMars 181-182).

18. Griffith, Wurster and Morley were included in the mailing list of Telesis friends and affiliates during the organization of Telesis's second show in 1950. SFMOMA Archives: ARCH.EXH.001, box 34, folder 13.

19. Morley's close relation with some Telesis members involved in her museum's activities, as well as her ongoing collaboration with Burton Cairns's widow Emmy Lou Packard -who was working with Diego Rivera on the «Pan American Unity» mural in conjunction with the Golden Gate International Exposition- facilitated the planning of the first Telesis exhibition at SFMA.

Feminismo/s 32, diciembre 2018, pp. 101-134 
Mocine, whom he brought into the group. Telesis members' professional training in the Depression, as well as the collaborative nature of the Roosevelt Administration's public programs, resulted in their broad concern for social problems and abiding commitment to shape the existing conditions for the better of their community.

Besides their involvement with New Deal programs, Telesis founder Francis Violich («Intellectual Evolution» 19-20) enumerated other early influences and motivators of the direction took by the group in the 1940s: F. L. Olmsted's and Daniel Burnham's Bay Area urban projects developed before World War I; William Wurster's regional approach to modern architecture, and, of course, their fascination with Lewis Mumford's social criticism. In his turn, Mumford would receive the feedback of their work as an inspirational source to further elaborate his arguments defending the enduring tradition of the Bay Region School's organic responses to time and place.

Telesis founders harbored a sense of «rebellion» against the formal conventionalisms of modern architecture, which they combined with an emphasis on the importance of the everyday life (Wurster 64). Their projects were embedded in the particularities of the Bay Area's local context, in which they aimed to intervene without destroying its exceptional landscape, so potentially conducive to its communities' good life. Telesis members agreed to conduct their research towards two fundamental goals: first, to explore the interdependence of their design fields; and secondly, to make the «man on the street» the center of their concern. They shared a strong faith in planning and in the importance of interdisciplinary collaboration as means to response to the organizational complexity, political relations and technologies that «make cities the stimulating holistic places they are» (Violich, «Intellectual Evolution» 5). Needing a name to launch their program, they adopted the Greek-based term «telesis $»^{20}$ as their slogan-definition of progress intelligently planned and directed, which, according to Violich («Intellectual Evolution»

20. «Telesis» word was first introduced by American sociologist Lester F. Ward to put forward his theory of cultural progress as a result of the underlying social forces facing the impersonal forces of natural evolution. Interestingly, as Peter Allen remarks, while most of the group's founding members recalled pulling the Greek word from a dictionary, its meaning was explained in an article published in The New York Times in October of 1939, exactly at the same time the group was deciding their name (Allen 82).

Feminismo/s 32, diciembre 2018, pp. 101-134 
19) encapsulated their common and deep-seated belief in: «a comprehensive and planned approach to environmental development; the application of social criteria to solving physical problems [...]; the team efforts of all professions that have bearing on the total environment; [and] the involvement of an informed public in the ultimate choice of potential solutions».

In this sense, assuming Grace Morley's vision of museums a places for community discussion, in their 1940 Space for Living exhibit the group showcased for the first time that architecture alone could not face environmental blight, meaning physical, politic and social deterioration, unless these interconnected problems -from neighborhood poverty to urban sprawl- were addressed together at scale of the entire Bay Area, as «coherent region in terms of what you see and how it feels to live there» (Eckbo, «Landscape Architecture» 53). Telesis's understanding of architectural innovation was also based in confronting social inequalities and racial segregation as part of their holistic design approach to the environment, a word that was by then rarely used but, thanks to them, came quickly into common vocabulary (Violich, «The Planning Pioneers» 29).

\subsection{Space for Living: «An Exhibit that Concerns You»}

When Grace Morley inspired Telesis to present their ground-breaking research to their fellow Bay Area residents, she was aware of the potential that such a timely discussion could have if the consortium was given the opportunity to lead the environmental debate in the public forum of her museum. For this reason, Morley offered the group the 4,500 square foot exhibit of the entire South Gallery with the sole condition to produce a trailblazing show up to the quality standards of her previous displays (DeMars 200). Taking on Morley's challenge, the 1940 showing was produced ${ }^{21}$ by Telesis founders themselves, being Garret Eckbo the coordinator of the content, Vernon DeMars in charge of the drawings, and Walter Landor responsible for the exhibition design.

21. For their second major show, held at SFMA in 1950, Telesis had considerably increased its membership to more than a hundred so, counting on more resources, the exhibition was produced by professionals hired for the occasion (DeMars 213) which resulted in a lack of freshness.

Feminismo/s 32, diciembre 2018, pp. 101-134 


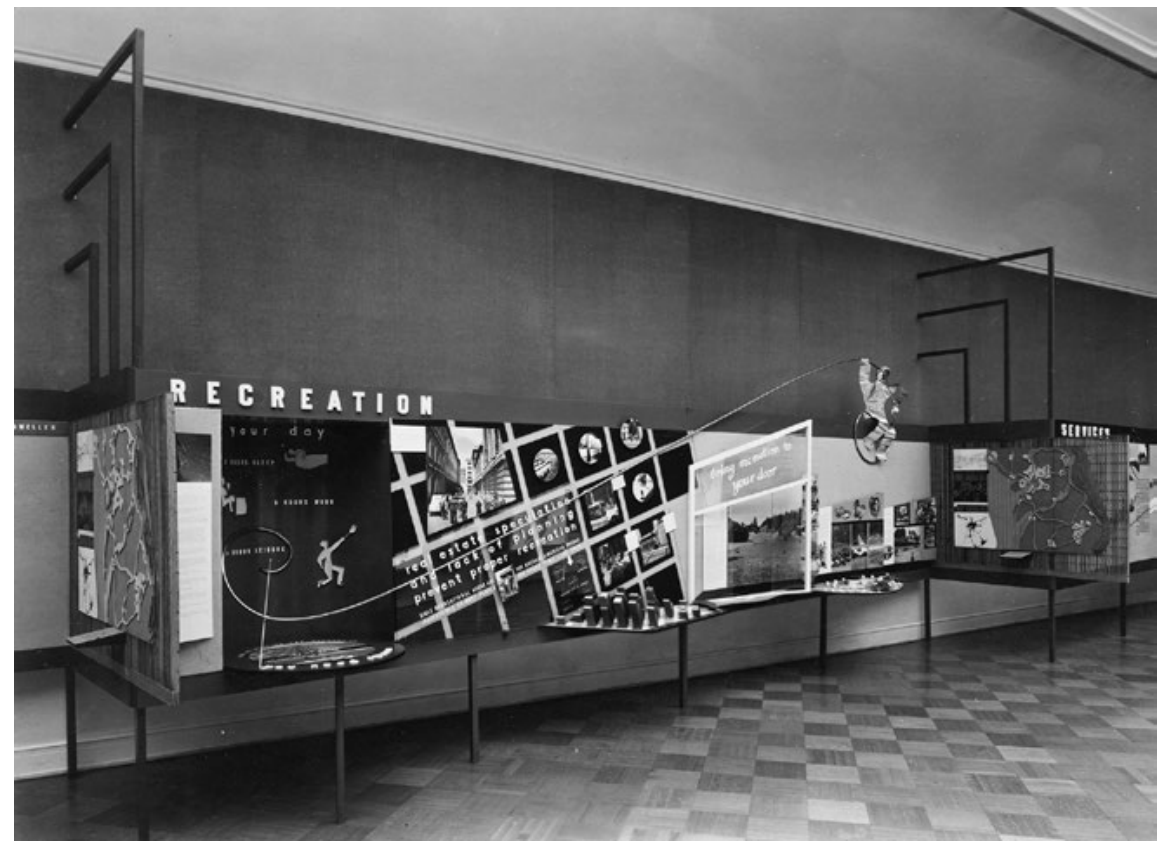

Figure 11. Telesis's 1940 Space for Living exhibition at SFMA's South Gallery. Courtesy of SFMOMA archives

Shortly before the war, some Telesis members -including DeMars- had met the Modern Architectural Research Group (MARS) in England, exposing them to CIAM ideology. Besides, they had been influenced by the straight messages Le Corbusier had put across in his 1938 book Des Canons, des Munitions? Merci! Des Logis S.V.P. claiming for social housing as an alternative to the ongoing rearmament (DeMars 200). To some extent, Telesis installation design for Space for Living recalled Le Corbusier's in the tent-like Pavilion of New Times at the Paris 1937 International Exposition. In fact, the 1940 exhibition articulated its discourse on the same four parameters highlighted by the Swiss master three years earlier: living (habiter), working (travailler), playing (recréer) and transporting (transporter) as components of human environments. However, instead of tackling these activities separately, Telesis aimed to reintegrated them to nature through a comprehensive planning

Feminismo/s 32, diciembre 2018, pp. 101-134 
dealing simultaneously with the many complexities of the Bay Area's milieu. Likewise, instead of giving preeminence to architectural design, the show laid emphasis on what Telesis considered the bases of every human environment: land and people, as the exhibition brochure stressed.

Space for Living proposed four major interrelated lines of action: modern architecture; modern city planning; regional projects for open spaces and multiple-scale green areas; and citizen participation in planning processes which, according to Catherine Bauer, was the "great political challenge of our time» (Bauer 70). DeMars's vivid sketches showed a visual contrast between images of urban decay -socially accepted as inevitable downsides of progress- and the vibrant solutions of environmentally efficient designs proposed to overcome housing problems. Also, Space for Living claimed against the devastating consequences of urban sprawl and the dominance of the automobile, warning about the dangers of destructing natural areas. Inspired by Mumford's ideas ${ }^{22}$, Telesis proposed constraining sprawl by funneling it into denser, compact towns and dedicating large areas of San Francisco Bay to open spaces contributing to a more livable and healthier environment. «Bring rural benefits to city dwellers. Bring agricultural greenbelts to the rescue of our cities ${ }^{23}$ the exhibit emphatically demanded. Additionally, as a reaction to the lack of integrated policies in the Bay Area -which was then fragmented among various local city and county agencies making separate land-use decisions-, Telesis advocated that the creation of a regional planning department was the only solution to controlling urban growth, preserving greenbelts, and solving transportation issues coordinately (Mocine, «Planning for the Region» 23). Finally, calling for a collective effort, Telesis asked for the support of civic groups, encouraging them to work together for the attainment of many of these objectives.

22. Particularly, The Culture of Cities resulted in profound importance for Telesis's urban thinking. Assuming Geddes's insightful analysis warning of the threats of spreading conurbations, as well as the contributions of Howard's Garden City model to prevent them, Mumford's 1938 landmark book claimed against the blurring limits of American metropolis as increasingly dispersed, low-density sprawl.

23. See Telesis's text for the exhibition catalogue. SFMOMA Archives: ARCH.EXH.001, box 13, folder 2 .

Feminismo/s 32, diciembre 2018, pp. 101-134 


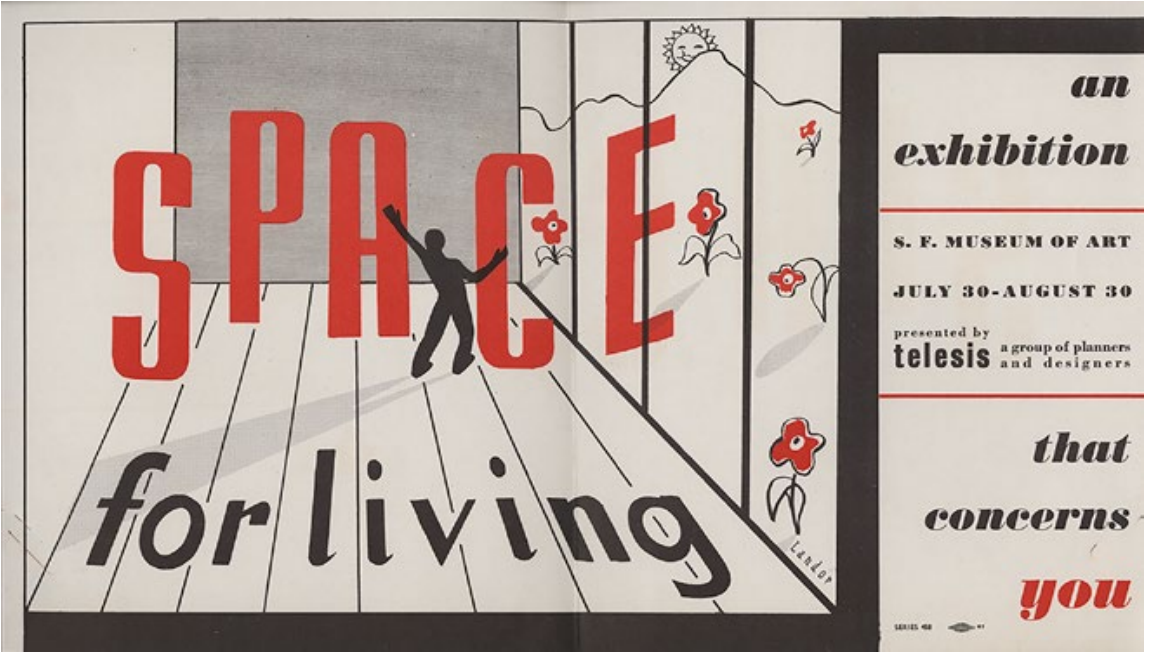

Figure 12. Telesis's 1940 Space for Living poster designed by Walter Landor. Courtesy of SFMOMA archives

The show, which was advertised as «An Exhibit that Concerns You», proved to be extremely effective in absorbing SFMA's audiences into its intelligent combination of message and display. In her introduction to the exhibition catalogue $e^{24}$, Morley remarked: «Telesis has found means of expressing in easily understood visual terms what the layman should know about environment planning, so that he may be able to follow intelligently what the professionals are prepared and able to do to assure him a better way of living». Due to the interchangeable nature of the subject and object of Telesis's research, the exhibition far exceeded Grace Morley's aim to both reach and learn from the average citizen. Space for Living altered the very nature of traditional museum displays. Rather than resort to conventional forms of exhibiting architecture, assert trends or produce fashion images to appeal visitors, the show inquired into complex issues to encourage public debates (Wright 87), questioning, for instance, about how good environmental decisions can improve people's lives. However, notwithstanding their focus on the message, the exhibit resulted in a display of major visual interest due

24. See Grace Morley's notes for the exhibition catalogue, July 1, 1940. SFMOMA Archives: ARCH.EXH.001, box 13, folder 2. 
to its attractive graphic design and thought-provoking composition of panels. As part of a didactic plot, the exhibition panels were linked by an undulating strip made of reproductions of newspapers articles featuring existing planning problems on which a visible lettering emphatically asked the open-ended question: «Is This the Best We Can Do?». Moreover, in order to facilitate the public understanding and participation in the show, Telesis members organized themselves to take turns and talk with the visitors, clear up their doubts, as well as draw out ideas from 'the man on the street' (Chermayeff ${ }^{25}$, «Birth of a Group» 47).

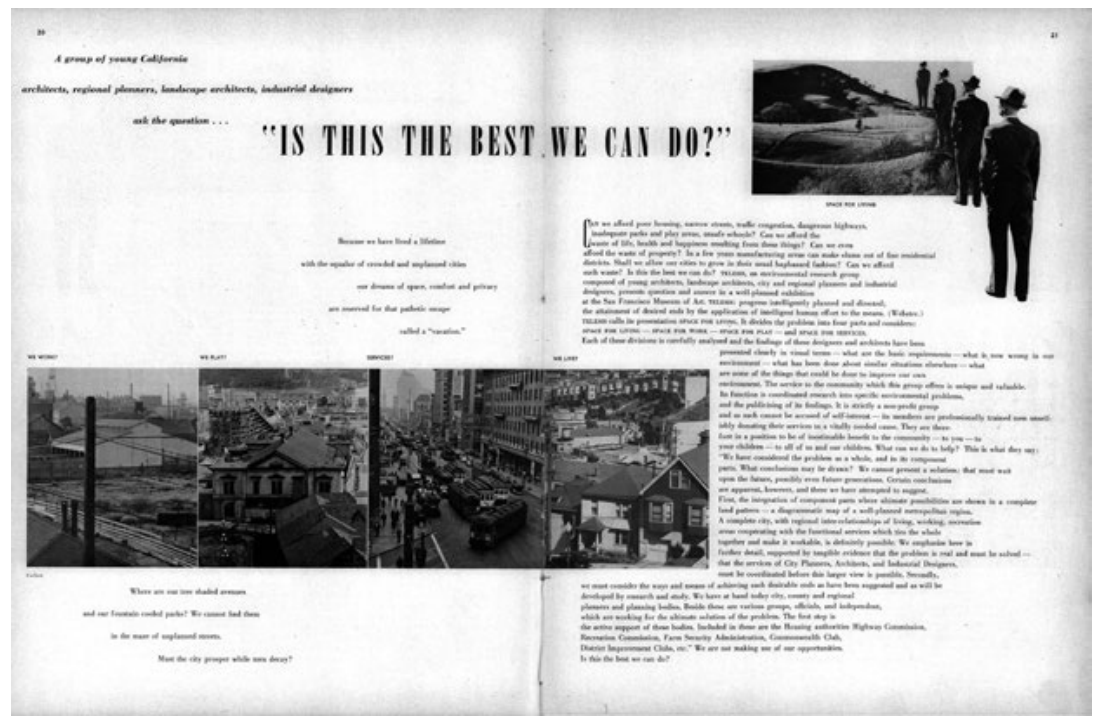

Figure 13. Central spread devoted to Space for Living show. California Arts \& Architecture, September 1940, issue

25. Upon his fortuitous relocation to the Bay Area, Serge Chermayeff -who was helped to establish himself professionally by Morley herself- realized of the potential of Telesis's research and gave a boost to the group's prestige, both by joining their discussions and writing several articles in which he praised Vernon DeMars's and Garret Eckbo's social housing projects as examples of the importance of planning over building (Chermayeff, «Birth of a Group», 46-47). Chermayeff also insisted that the measure of the Californian contribution to modern architecture design had not to be sought in its attractive residences but in other «things that until quite recently received little publicity», such as the «various camps, labor homes, farms and community buildings» designed by Telesis members for the FSA (Chermayeff, «Architecture and a New World», 40).

Feminismo/s 32, diciembre 2018, pp. 101-134 


\subsection{The Political Impact of the 1940 Telesis Show}

Space for Living triggered a change of mindset as regards the perception of the Bay Area as a whole environment composed of intertwined urban structures and natural systems. The show indisputably became one of the most popular events in the history of the San Francisco Museum of Art. Over four weeks, it was attended by more than 10,000 Bay Area residents who flocked to SFMA attracted by the idea of a comprehensive planning for the region.

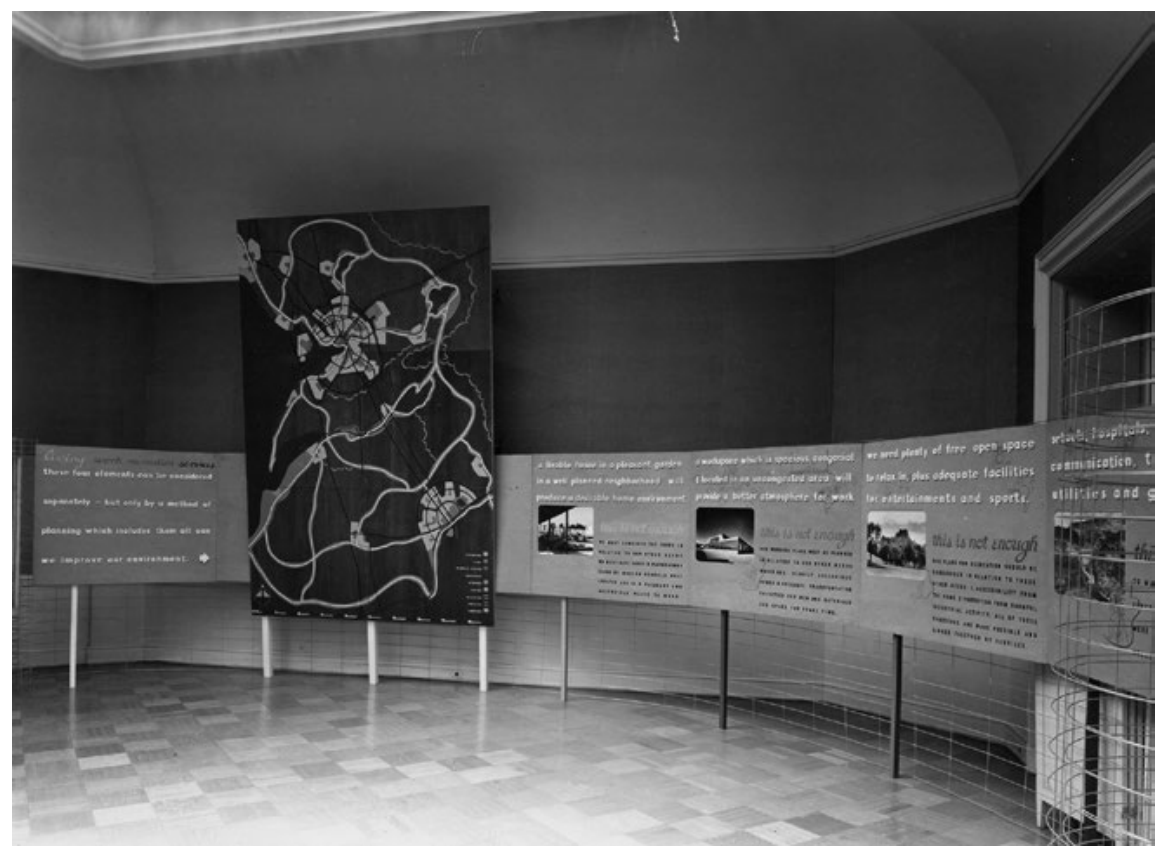

Figure 14. Telesis's 1940 Space for Living exhibition at SFMA's South Gallery.

Courtesy of SFMOMA archives

The public's enthusiasm put Telesis's challenges at the forefront of the most significant local debates since, in 1940, the consolidated city and county of San Francisco was still one of the few major American metropolis lacking a professional city planning commission. The show and its subsequent public discussions contributed to changing this situation and built momentum

Feminismo/s 32, diciembre 2018, pp. 101-134 
towards the establishment of an effective planning department. Consequently, despite remaining as a large, diffuse group which never constituted an office, Telesis become a crucial actor in the political life of San Francisco. Only three months after the closing of the show, they managed to involve most of the civic leaders, planning bureaucrats and governmental agents who had visited the exhibit in a social coalition to prompt the city officials to professionalize the planning commission. Telesis's lobbying effort resulted in the constitution, in 1942, of San Francisco's first Department of City Planning, whose staff included Francis Violich and Jack Kent, being the latter appointed its second Director in 1946, and responsible for the coordination of a master plan demanding citizen participation (Allen 72-73).

After a couple of transitional displays ${ }^{26}$, Telesis's arguments were reframed in their second major and last exhibition: The Next Million People. It was organized on the occasion of the tenth anniversary of Space for Living and took place at SFMA from September 20 to October 29, 1950. After 1945, however, the group cohesion -if not its idealism (Treib 47) had faded due to the impending demand $s^{27}$ of the postwar era and their energies redirected toward integration into the mainstream of increasingly professionalized activities, planning offices and academic institutions such as the University of California (UC) Berkeley whose Department of City and Regional Planning, was founded in 1948 by Telesis members Jack Kent and Francis Violich under

26. Gwendolyn Wright recalls a smaller exhibit organized by Telesis two years after the 1940 show. Entitled Women in the War, it stressed gender issues, such as child care, not only in defense housings but as an alternative model for future planning and design deliberations (Wright 87). However, as SFMOMA archivist Peggy Tran-Lee has confirmed, there are no records of this show despite appearing on the exhibition calendar in November 1943. Yet, there is evidence of another show attributed to Telesis, Planning for Safety and Better Living: Suggestions for Post-War California held at SFMA from April 12 to May 2, 1943. Its exhibition file (ARCH.EXH.001, box 18, folder 37) contains materials of Carl Troedsson's The City-Town of Tomorrow exhibit, whose installation was coordinated by Dorothy Erskine, most likely as part of a larger show composed of miscellaneous materials.

27. Telesis's environmental endeavor can be framed in the historical context of what Andrew Shanken defines as the "culture of planning» of the 1940s which, having emerged in the Great Depression, faded with the increasing conservatism of the postwar years, "when Americans dreamed of abundance and were about to have unprecedented access to it» (Shanken 195).

Feminismo/s 32, diciembre 2018, pp. 101-134 
guidance from their close friends and mentors William Wurster and Catherine Bauer. Their final contribution before dissolving would came in academia when UC Berkeley Architecture School dean William Wurster -perhaps echoing his previous reorganization of MIT- encouraged them to reorganize the Departments of Landscape Architecture, City and Regional Planning, and the College of Architecture into one single administrative entity eloquently renamed as the College of Environmental Design. Ironically, soon after Grace Morley left the Bay Area for good, in 1959, the new School would bring together the fields of landscape architecture, architecture and planning -to which tellingly Morley's had devoted her first architectural exhibits-, to scholastically explore their many intersections over the basis of shared scientific, cultural and social concerns.

\subsection{The unrecognized role of women}

However remarkable the consequences of the 1940 exhibition were, the contributions of Telesis female members and supporters to it remain insufficiently recognized by both scholarship and popular accounts. Peter Allen's excellent doctoral thesis brings attention to the profoundly important role that women played during the postwar years to reconcile modern architecture with the qualities of regional place. Yet, as Allen remembers, they are often «only appreciated as wealthy, married women with plenty of free time and important social connections». While this was, of course, an important part of women's political power that time, it completely overlooks that professional or semi-professional women participated actively in environmental activism (Allen 7).

Among, these professional women, Grace Morley -who is barely mentioned in a couple of footnotes in Allen's dissertation- must be credited as the main person responsible for the idea of mounting and promoting so extraordinary a show. Morley's support to Telesis's vision was instrumental to the organization of the 1940 show and, more importantly, to the creation of the group itself. In fact, Telesis was not really brought to life until their members' ideas were articulated, discussed and become known by means of this exhibition. Additionally, having been introduce to John Entenza in the spring of 
1940, Morley used her influence to get published a central spread featuring the show in the September, 1940 issue of California Arts $\&$ Architecture.

Likewise, Catherine Bauer was not only the group's strongest intellectual reference but also one of their major facilitators. For instance, while teaching at Harvard University in the 1940s, Bauer served as editor of the reputed student journal Task, to which Francis Violich, Vernon De Mars, and Garrett Eckbo would also contribute.

Another example of professional woman is notorious landscape designer and scholar Geraldine Knight Scott, who having been an active member of Telesis from its beginning, played a major role in extending the group's activities further south from San Francisco. She, along with her husband, journalist and planner Mel Scott, started a Los Angeles branch of Telesis where, in the fall of 1941, they mounted Now We Plan, a germane exhibition to the original 1940 show focusing on the Southern California region.

As to the group of non-professional Telesis female affiliates, Dorothy Erskine must be mentioned as «perhaps the most important Bay Area environmentalist of the period from the 1940s to the 1960s because of her role as a grass-roots catalyst» (Allen 78) as, virtually all Bay Area environmental organizations relied on her network of social and political connections ${ }^{28}$. In fact, in the case of the Space for Living show, she was pivotal to provide financial assistance to put together the 1940 exhibit and to ensure the attendance of civic leaders. Erskine, along with Bauer's close friend Alice Griffith mobilized San Francisco communities to receive endorsements from public figures and cultural institutions across California and beyond, like the Museum of Modern Art, New York, via Bauer's sister Elizabeth Mock, who must have found Telesis's first show inspirational, as the similarities with her 1944 Look at Your Neighborhood! exhibit reveals.

28. Erskine explained in a 1971 interview that, by then, only independent woman had the time to accomplish the day-to-day «grind» of writing pamphlets, licking stamps, and making phone calls. Erskine worked from the idea that, "when groups come together, they create new ideas» so much of her activist work was therefore about connecting people (Allen 78).

Feminismo/s 32, diciembre 2018, pp. 101-134 


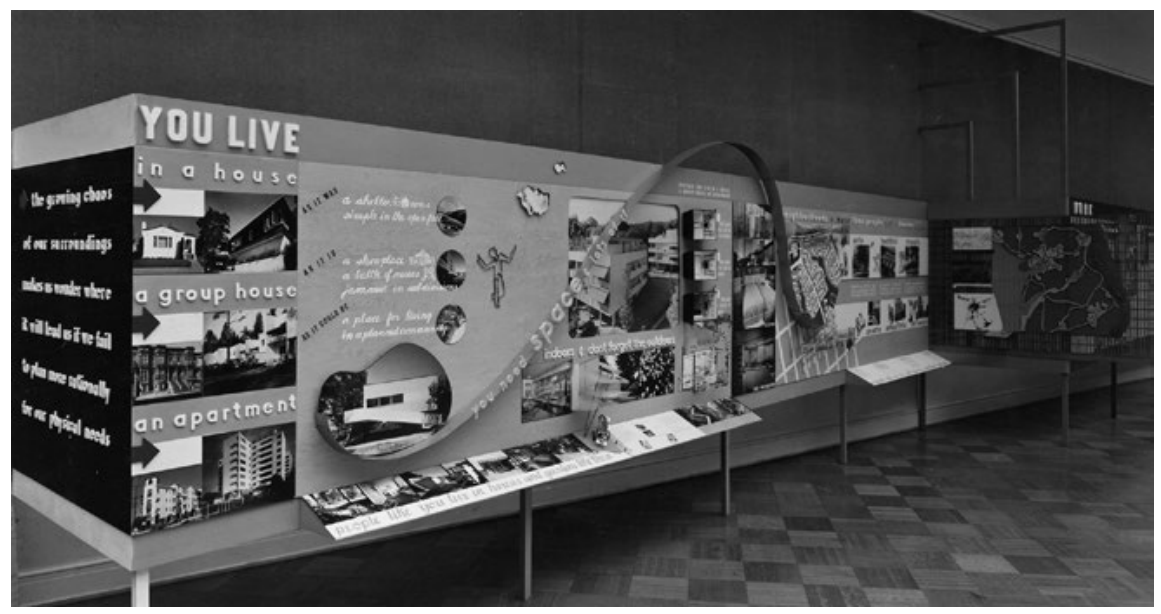

Figure 15. Telesis's 1940 Space for Living exhibition at the San Francisco Museum of Art. Courtesy of SFMOMA archives

Furthermore, it would not be unreasonable to hold that Dorothy Erskine's activism could have even inspired the work of renowned professionals such as Catherine Bauer, among others. Indeed, Bauer's anti-sprawl 1960 memorandum The California Environment: Must It Be Ruined by Growth and Prosperity ? $^{29}$ was a scholarly complaint about the extent to which «a wider spread of suburban sterility» was spoiling landscapes of unique natural value, for whose preservation, as an integral part of the life and culture of the West, Dorothy Erskine had untiringly crusaded for decades in the streets of San Francisco. Embracing Telesis's defense of city density against uncontrolled urban sprawl, Erskine struggled to make citizens and political leaders aware of the moral obligation to preserve the open space of urban hills, farmlands and natural areas of the Bay Area for future generations (Erskine, «Interview»). She, along with Jack Kent, committed themselves to the founding of Citizens for Regional Parks and Open Space, the first open-space advocacy group in the region, which evolved into People for Open Space and ultimately into Greenbelt Alliance. Additionally, in 1961, Erskine supported the creation of

29. Bancroft Library, UC Berkeley. Catherine Bauer Papers, 1931-1964. BANC.MSS 74/163c, carton 1.

Feminismo/s 32, diciembre 2018, pp. 101-134 
Esther Gulick's, Kay Kerr's and Sylvia McLaughlin's Save the Bay organization, becoming a model for these and future activist women ${ }^{30}$ who managed to mobilize thousands of Bay Area residents to protect and restore some of the most ecologically valuable waterfronts of San Francisco Bay from local governments' attempts to landfill them for industrial and real state purposes.

\section{CONCLUSIONS}

Through a diversity of alliances surrounding the San Francisco Museum of Art's channels, West Coast architects were able to put forward a public agenda which resulted in the leading some of the most significant American postwar debates and in establishing for the architectural tradition of the Bay Area a room in the pantheon of architectural history. More importantly, director Grace Morley's primary aim to conceive architectural exhibitions in terms of effective displays for the public's enlightenment was a successful endeavor. Decades before terms such as 'environmentalism', 'sustainability' or 'smart' growth were coined, Morley's insightful shows like Telesis's Space for Living contributed to the public's awareness of the many dangers of shortsighted planning and to stressing the importance of a more complex, regional approach to anticipate long-term strategies undertaking San Francisco Bay's environmental challenges. Although Telesis's vision was never fully adopted, Space of Living's stance that social, gender and race inequalities were intertwined with deficient planning policies still remains valid. Thanks to Morley, but also to a pool of talented, dedicated women whose contributions still deserve proper recognition, Telesis 1940 show became a primary force in the creation of the San Francisco City Planning Department and gave impetus to the adoption of a coherent master plan, having a tremendous impact on the rise of the ecological conscience of San Francisco Bay Area as home to a progressive and well-established environmental movement.

30. Green advocate Sylvia McLaughlin stated that, in most cases, such as Dorothy Erkine's, women did most of the work but «there was always a man who headed up the organization» (McLaughlin 105).

Feminismo/s 32, diciembre 2018, pp. 101-134 


\section{BIBLIOGRAPHICAL REFERENCES}

«AIA Exhibition of Architecture, San Francisco». Architectural Forum 68. December (1938): 468-469.

Allen, Peter A. A Space for Living: Region and Nature in the Bay Area, 1939-1969. Diss. UC Berkeley, 2009.

Bauer, Catherine. «Planning is Politics, but are Planners Politicians?». Pencil Points 25. March (1943): 66-70.

Born, Ernest. «Exhibition of Residential Architecture». California Arts $\mathcal{E}$ Architecture 58. June (1941): 24-25.

Chermayeff, Serge. «Architecture and a New World». California Arts \& Architecture 58. May (1941): 12-13, $38 \& 40$.

— «Birth of a Group. Telesis». Pencil Points 23. July (1942): 45-48.

DeMars, Vernon. "A Life in Architecture: Indian Dancing, Migrant Housing, Telesis, Design for Urban Living, Theater, Teaching». Oral History conducted in 1988-89 by Suzanne Riess. Regional Oral History Office. Bancroft Library. UC Berkeley, 1992.

Eckbo, Garret. «Landscape Architecture. The Profession in California, 1935-1940, and Telesis». Oral History conducted in 1990 by Suzanne B. Riess. Regional Oral History Office. Bancroft Library. UC Berkeley, 1993.

- Space for Living. New York: Duell, Sloan and Pearce, 1950.

Erskine, Dorothy. «Interview». San Francisco History Center, San Francisco Public Library, 1978. <https://www.youtube.com/watch?v=iMwFKfEgj10>, last accessed May 21, 2018.

- «The San Francisco Planning and Urban Renewal Association». Interview conducted in 1971 by John Jacobs. Bancroft Library. UC Berkeley.

Kirk, Kara. «Grace McCann Morley and the Modern Museum». San Francisco Museum of Modern Art: 75 Years of Looking Forward. Ed. Janet Bishop, Corey Keller and Sarah Roberts. San Francisco: SFMOMA, 2009. 71-77.

Knight Scott, Geraldine. "A Woman in Landscape Architecture in California, 1926-1989». Oral History conducted in 1976 by Jack Buktenica. Regional Oral History Office. Bancroft Library. UC Berkeley, 1991.

Martenyi, Megan. «Wide Open Publics: Tracing Grace McCann Morley's San Francisco». SFMOMA, August 2017. <https://www.sfmoma.org/essay/wideopen-publics-tracing-grace-mccann-morleys-san-francisco/>, last accessed May 29, 2018.

Feminismo/s 32, diciembre 2018, pp. 101-134 
McLaughlin, Sylvia. «Citizen Activist for the Environment: Saving San Francisco Bay». Interviews conducted in 2006-2007 by Ann Lage. Regional Oral History Office. Bancroft Library. UC Berkeley, 2009.

Mocine, Corwin. «Planning for the Region.» California Arts and Architecture 51. April (1941): $23 \& 45$.

— «Space for Living.» California Arts and Architecture 50. September (1940): 20-21.

Mock, Elizabeth. Built in USA: 1932-1944. Exh. cat. New York: MoMA, 1944.

Morley, Grace L. M. «Art, Artists, Museums and the San Francisco Museum of Art». Interview conducted by Suzanne Reiss. Regional Cultural History Project. Bancroft Library. UC Berkeley, 1960.

- «Foreword». Contemporary Landscape Architecture. Exh. cat. San Francisco: SFMA, 1937. 13-14.

- Oral History Interview conducted in 1982 by Porter McCray. Archives of American Art. Smithsonian Institution, 1982.

Mumford, Lewis. «The Architecture of Bay Region». Domestic Architecture of the San Francisco Bay Region. Exh. cat. San Francisco: SFMA, 1949.

- The Culture of Cities. San Diego, New York: HBJ Publishers, 1970 (1938).

— «The Sky Line: Status Quo». The New Yorker, September 11 (1947): 106-109.

Olsberg, Nicholas. Architects and Artists: The Work of Ernest and Esther Born. San Francisco: The Book Club of California, 2015.

Shanken, Andrew. 194X. Architecture, Planning, and Consumer Culture on the American Home Front. Minneapolis: University of Minnesota Press, 2009.

Treib, Marc. "The Social Art of Landscape Design». Garret Eckbo. Modern Landscapes for Living. Ed. Marc Treib and Dorothée Imbert. Berkeley-Los Angeles: University of California Press, 2005 (1997). 1-105.

Wright, Gwendolyn. «Practicing Pragmatism in Urban Metropolitan Design». Making the Metropolitan Landscape. Standing Firm on Middle Ground. Ed. Jaqueline Tatom and Jennifer Stauber. London-New York: Routledge, 2009. 81-96.

Violich, Francis. «Intellectual Evolution in the Field of City and Regional Planning». Working Paper. UC Berkeley, 2010.

- «The Planning Pioneers». San Francisco Chronicle. California Living Weekly Magazine 26. February (1978): 29-35. 
Wurster, William W. «College of Environmental Design, University of California». Interview conducted by Suzanne Reiss. Regional Cultural History Project. Bancroft Library. UC Berkeley, 1964.

\section{ACKNOWLEDGEMENTS}

This chapter would have not been possible without the help of Peggy Tran-Le, archivist and records manager at the San Francisco Museum of Modern Art, who has facilitated our research by actively guiding us through the extraordinary collections of exhibition records pertaining to Grace McCann Morley's years as SFMA director. 